\section{Influence of Plant Storage Duration on Strawberry Runner Tip Viability and Field Performance}

\author{
Stan C. Hokanson ${ }^{1}$ \\ Department of Horticultural Science, University of Minnesota, St. Paul, MN 55108
}

Fumiomi Takeda ${ }^{2}$

Appalachian Fruit Research Station, United States Department of Agriculture, Agricultural Research Service, 2217 Wiltshire Road, Kearneysville, WV 25430

John M. Enns ${ }^{3}$ and Brent L. Black ${ }^{4}$

Fruit Laboratory, United States Department of Agriculture, AgriculturalResearch Service, 10300 Baltimore Avenue, Beltsville, MD 20705-2350

Additional index words. plug plants, tissue culture, plant propagation, container plants, transplants, annual culture, plasticulture

\begin{abstract}
Tissue-culture derived mother plants were established in a greenhouse suspendedgutter, nutrient-film technique growing system to evaluate runner tip productivity in the system. Effects of cultivar ('Allstar', 'Chandler', 'Latestar', 'Northeaster', and USDA selection B 27) and duration ( $\left(0,1\right.$, or 2 months) of cold storage at $1^{\circ} \mathrm{C}$ on tip viability, rooting success, and performance in fruit production were determined. The average number and weight of runner tips produced in the gutter production system, the capacity of runner tips to form cohesively rooted plug plants, and the number and length of adventitious roots produced by runner tips varied significantly among the cultivars and the three storage durations $(0,1$, or $\mathbf{2}$ months). In the field, plants produced from runner tips stored for $\mathbf{2}$ months produced more runners than plants produced from freshly harvested runner tips. Crown number differed among the cultivars, but was not affected by cold storage treatment. No treatment differences were noted for the fruit harvest parameters evaluated. The results suggest that the transplants derived from mother plants grown in a greenhouse-based soilless system can be useful for annual plasticulture strawberry production in colder climates. Although long periods of cold storage of runner tips resulted in lower tip-to-transplant conversion ratios, field performance of transplants was not adversely affected. Additional research is needed to improve greenhouse strawberry production practices for increasing runner output and storage conditions that maintain the integrity of cold-stored runner tips. Without these improvements it is unlikely that soilless runner tip production will become a widely accepted technique that would replace the field nursery tip production method currently used by commercial strawberry propagators.
\end{abstract}

Strawberry (Fragaria $\times$ ananassa Duchesne) growers in the Southeastern, mid-Atlantic, and mid-western production regions of North America (USDA Plant Hardiness Zone 5, 6, and 7) are adapting the annual hill strawberry production system developed in California(Voth and Bringhurst, 1990) to these production areas (O’Dell and Williams, 2000; Poling, 1993; Poling and Durner, 1986). The benefits of the system include: bringing a planting into production in 7 to 8 months, producing larger sized, clean, well-displayed, easy-to-pick fruit earlier in the season, generating early season premium fruit prices, and controlling weeds with plastic mulch. Two of the many parameters of the system that will require optimization for colder production

Received for publication 27 May 2003. Accepted for publication 15 Mar. 2004. We gratefully acknowledge Kate Salazar for micropropagation of strawberry plants used in the study and Ann K. Hummell for her excellent technical support.

${ }^{1}$ Assistant professor. Previously, research geneticist in the Fruit Laboratory.

${ }^{2}$ Research horticulturist.

${ }^{3}$ Horticulturist.

${ }^{4}$ Plant physiologist.

regions are the cultivar and the plant type used. The cultivar Chandler is most widely used; however, it is clearly desirable to have more cultivars with improved winter hardiness and adaptation to more northern climates to improve the annual plasticulture system in these regions.

The plant type is a concern for the annual plasticulture system. Historically, dormant or frigo plants were used in California. Much of that industry now uses fresh-dug plants from high elevation nurseries in the state. Florida growers use fresh dug Canadian plants (Hicklenton and Reekie, 2002). Each of these transplant types have presented problems for the mid-Atlantic coast growers using the annual plasticulture system. Dormant plants of most of the desired cultivars are readily available for summer or fall planting in August to September, but by then these plants have been in storage for nearly 1 year and often show reduced vigor and survival (Hicklenton and Reekie, 2002). Also, an efficient, mechanized transplanting system has yet to be adapted for dormant plants, leading to increased labor costs.

Fresh-dug plants require daily overhead irrigation for 1 to 2 weeks after planting for suc- cessful establishment. In addition to using large volumes of water, this irrigation regime greatly increases the potential for pathogen outbreaks (Reynolds et al., 1987; Yang et al., 1990), soil erosion, and nutrient leaching (El-Farhan and Pritts, 1997). Fresh plant production in Canada has been oriented toward the Florida industry, thus limiting the choice of available cultivars to those adapted to winter production in the Florida industry. Also, fresh-dug Canadian plants are not available until the third week of September, past the best planting dates (mid-August to mid-September) in the colder production areas of the eastern seaboard and midwestern United States.

Production of transplants in the field increases the possibility of exposure to soil-borne pathogens (Maas, 2000). Although nursery soils are fumigated to reduce disease risk, recent studies on some epidemiological factors such as spore dispersal, alternative hosts, soil persistence and symptomless infections for strawberry diseases such as anthracnose (Leandro et al., 2001) and phytophthora crown rot suggests that soil fumigation may not be adequate in ridding the soil of pathogens. Reducing transplant exposure to potential pathogens could be a prudent strategy.

More recently, the use of plug transplants in annual plasticulture system has increased in the eastern United States (Poling and Parker, 1990). The perceived advantage of plug transplants include the ability to use mechanical transplanters, reduced irrigation requirements during field establishment, reduced root damage compared to mechanically harvested fresh-dug plants, and the potential for a later planting date with no reduction in fruit yield or quality (Hicklenton and Reekie, 2002). Perhaps the most important benefit is the potential to reduce the occurrence of several important strawberry diseases, including those caused by Phytophthora cactorum (Lebert \& Cohn) J. Schröt. and Colletotrichum spp., by reducing exposure of transplants to sources of inoculum (Maas, 2000).

A key component to reducing the exposure of transplants to pathogen contamination would be to restrict runner tip and plug plant production to the greenhouse. One greenhouse production strategy would involve planting large numbers of mother plants in suspended containers and allow the plants to form long stolon strings with several runner tips. In one single operation the strings would be harvested, runner tips would be trimmed, graded and planted. Such a strategy would require a large crew to process the plant material in a timely fashion. Another runner tip production strategy would involve multiple runner tip harvests, with harvested tips cold-stored for later rooting. This would spread labor requirements over the season and all tips could be plugged about 4 weeks before the narrow planting window. Such a strategy would be based on the knowledge that the runner tips could be stored for 2 or 3 months without reduction in plant viability, establishment or field performance.

We evaluated the potential for producing and storing runner tips in a continuous fashion from tissue culture-produced mother-plants grown in the greenhouse in a suspended gutter system 
(Takeda, 1999; Takeda and Hokanson, 2002). Our objectives were to evaluate 1) the runner tip production capacity of several tissue-culture derived strawberry cultivars in this greenhouse system, 2) the effects of cold storage duration on runner tip viability and subsequent field performance, and 3) the potential variation among cultivars in response to cold storage.

\section{Materials and Methods}

Plant materials. Four strawberry cultivars commonly used by growers in the annual production system in the eastern U.S., and one advanced selection from the USDA Beltsville breeding program were used in these experiments. They included the cultivars Allstar (Galletta et al., 1981), 'Chandler' (Voth and Bringhurst, 1984), 'Latestar' (Galletta et al., 1996) 'Northeaster' (Galletta et al., 1995a) and B 27 ('Lateglow' x 'Seneca') a late midseason type USDA selection. 'Allstar', 'Latestar', and 'Northeaster' were developed for and are most commonly used in the traditional matted row production system.

Plant production. Tissue culture plantlets maintained at the USDA Fruit Laboratory in Beltsville were the source stock for all plant material used in these experiments. Single explants of each cultivar were subcultured onto Stage II strawberry shoot proliferation media described by Swartz et al., (1981) with the addition of $4.4 \mu \mathrm{m}$ 6-benzyladenine. Shoots were grown in French square culture jars (Brockway Inc., Brockway, Pa.) under cool white fluorescent lights set for a $16-\mathrm{h}$ photoperiod at 39 $\mu \mathrm{mol} \cdot \mathrm{m}^{-2} \cdot \mathrm{s}^{-1}$ and $25^{\circ} \mathrm{C}$. Clumps of proliferated crowns were divided and planted into 48- cell, $3.8 \times 8.57 \times 8.57 \mathrm{~cm}$, rigid plastic trays (Geiger Co., Harleysville, $\mathrm{Pa}$.) containing a peat-perlite growing media (Metro-Mix 510, Geiger Co., Harleysville, $\mathrm{Pa}$.). Plantlets were grown under intermittent mist sprinklers until they developed a cohesive root ball that could be removed intact from the cell pack.

Plants with fully developed root systems were transplanted into 0.95-L mesh pots (Springdale Aquatic Nursery and Supply, Greenville, Va.) containing planting media supplemented with perlite and grown under natural light supplemented with overhead incandescent lighting to ensure a 16-h photoperiod. Pots were placed on heating mats set at $21.1{ }^{\circ} \mathrm{C}$ until the root system extended to the bottom of the meshed pot, at which point they were transported to greenhouses at the USDA-ARS Appalachian Fruit Research Station in Kearneysville, W. Va.

Greenhouse cultural system. On 27 Apr. 1999, plants were established in nutrient film technique (NFT) culture described by Takeda et al. (1997). Pots were set into the gutters at a 30.5-cm spacing, with the five cultivars arranged in a randomized complete block design with four replications. The greenhouse was maintained at $23{ }^{\circ} \mathrm{C}$ day and $18{ }^{\circ} \mathrm{C}$ night temperatures and photoperiod was extended to 16-h using 1,000Whigh pressure sodium lamps $\left(115 \mu \mathrm{mol} \cdot \mathrm{m}^{-2} \cdot \mathrm{s}^{-1}\right.$ at plant canopy height).

Runner tip production. Runner tips to be used in the storage treatments were collected during three harvest periods: 20-24 May (two harvests), 14-24 June (four harvests), and on 20 July. Tips from the first two harvests were stored by cultivar in sealed plastic bags at $1{ }^{\circ} \mathrm{C}$ until the third harvest on 20 July. The three harvest dates resulted in runner tip storage treatments of 0,1 , and 2 months. Runner tips were also harvested, counted and discarded on six other dates from May through July to quantify total runner production capacity. At each harvest, tips were counted and weighed. On 20 July, runner tips from all storage treatments were planted into 48-cell rigid plastic trays filled with Metro-Mix 510 planting media. The runner tips were placed under intermittent mist at ambient temperature for 10 days until a cohesive root system was formed.

Adventitious root development and plug plant formation were assessed as follows: after seven days under intermittent mist, primary root number and length of the longest root were taken on two randomly selected plug plants from each plot of each cultivar and storage treatment. At $21 \mathrm{~d}, 12$ plug plants of each cultivar and storage period were gently removed from the rooting container to assess survival and root ball formation. The plant was considered transplantable if all the rooting media could be pulled out of the container intact. Values for percent transplantable plug plants were transformed with the arcsine of the square root of the individual percent prior to statistical analysis.

Field evaluation of plug plants. On 12 Aug. 1999, the plug plants were established in a field planting at Beltsville, Md. after the methods described by Black et al. (2002). Six plant plots were randomized in a complete block design with four replications for each cultivar/treatment

In September and October of 1999, runner and branch crown numbers were recorded for each plant. Runners were removed by hand at the conclusion of each count. Beginning on 11 May 2000, and continuing twice weekly until 19 June, all ripe strawberries were harvested from the plots. At each harvest, the following data were collected; total plot yield, average weight of 10 randomly selected fruit, and a subjective rating of marketable yield based on the percentage of small, misshapen, diseased or damaged fruit (Galletta et al., 1995b). The marketable yield score was based on a 1-9 scale, in which a 9 was assigned to a harvest when $100 \%$ of berries were considered marketable and a 1 to a harvest with no marketable berries. A score of 7 was considered an average marketable score. An average score was calculated from all 10-fruit subsamples at each harvest date during the 2000 harvest season. Also, the season of production, expressed as the percent of yield that was harvested in the first two pickings of the season (16 May 2000), and average fruit size for the largest fruit picked in the season were calculated.

Statistical analysis. Analysis of variance (ANOVA) for treatment and cultivar was carried out using the GLM procedure of SAS (2001). Where there was no cultivar $\times$ treatment interaction, means separation was by Duncan's multiple range test $(P \leq 0.05)$. In cases where cultivar $\times$ treatment interaction was significant, individual paired comparisons were made using the PDIFF option of the LSMEANS statement.

\section{Results}

Runner tip production. Runner tips were collected from mother-plants on thirteen dates in May, June, and July 1999 (Fig. 1). The average number of runner tips produced by each mother-plant growing in the gutter production system differed significantly among cultivars and date of harvest (Fig. 1). Significant cultivar by harvest date interactions were observed. The

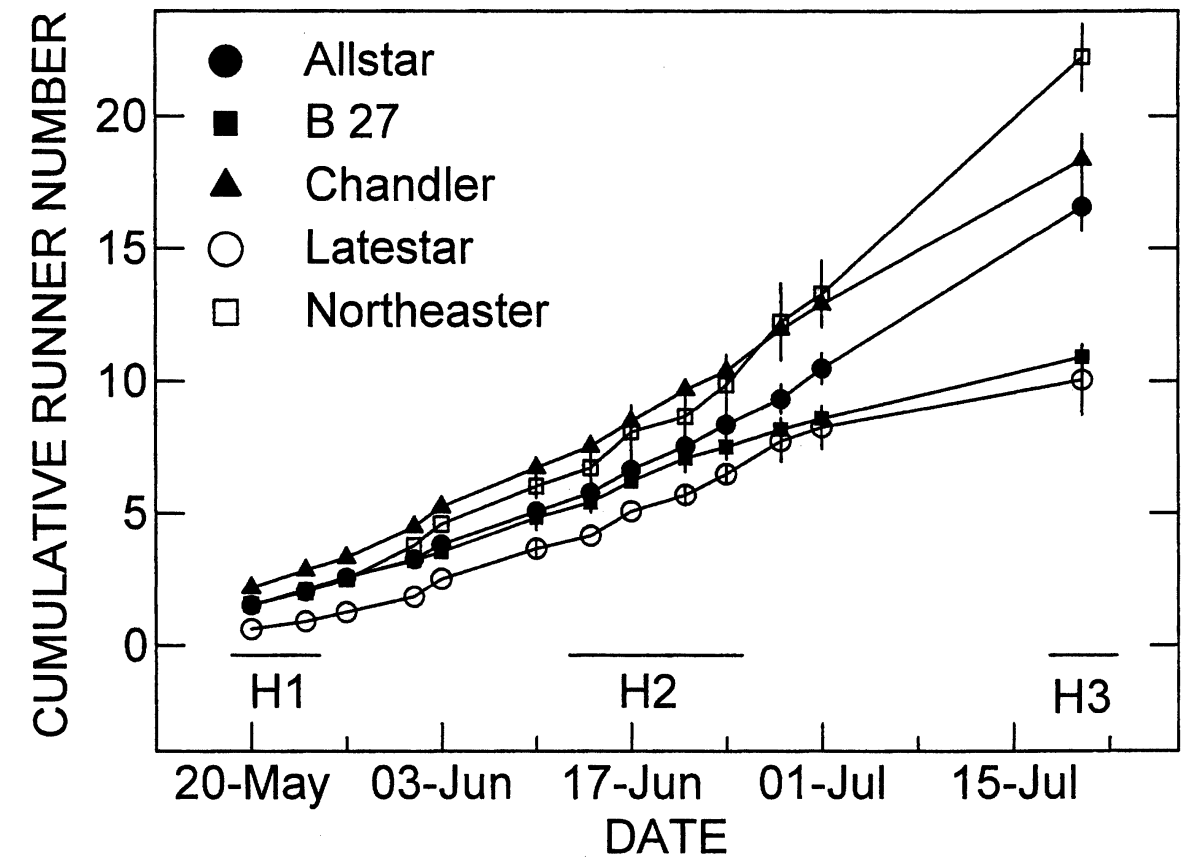

Fig. 1. Numbers of runner tips harvested from each mother plant over thirteen dates from 20-24 May (H1), 14-24 June (H2), and 20 July (H3). These are expressed cumulatively as a function of date. Mother plants were grown in the suspended gutter system at Kearneysville, W.Va. 
runner tips produced per plant ranged from 22 for 'Northeaster' to 10 for 'Latestar' (Fig. 1).

Average fresh weight of the runner tips at harvest differed significantly by cultivar and date of harvest (Table 1). Significant cultivar by harvest date interactions were observed. Average runner tip weights at harvest ranged from $4.8 \mathrm{~g}$ for B 27 to $2.9 \mathrm{~g}$ for 'Latestar' and increased through the later harvest dates with the highest average runner tip weights recorded for runner tips harvested in July. Runner tip weights were also measured at the conclusion of the storage treatments, but tips showed no change from prestorage weight (data not shown).

Runner tip rooting capacity. Significant differences were noted among cultivars for adventitious root number and the length of the longest root (Table 2). Average root numbers ranged from 10.9 roots per plant for 'Chandler' to 4.7 for B 27 . Significant cultivar by storage duration interactions were noted for adventitious root number. Average maximum root length ranged from $5.1 \mathrm{~cm}$ for 'Latestar' to $3.8 \mathrm{~cm}$ for B 27. Significant differences among storage treatments were also noted for root production with the fewest number (4.1) produced by runner tips stored for 1 month. No significant differences were noted in root length among storage treatments.

Cultivar and storage duration effects were noted in the capacity for runner tips to form cohesively rooted field-transplantable plants after three weeks under intermittent mist (Table 2 ). The percentage of runner tips that formed rooted plugs ranged from $86 \%$ for 'Latestar' to $72 \%$ for 'Allstar'. The highest percentage of transplantable plants was produced with fresh plugged tips. Storage durations of one and two months reduced the percent transplantable values to $77 \%$ and $71 \%$ respectively. For all cultivars, about $8 \%$ of runner tips failed to produce adventitious roots. In these failed tips, the nodal region became necrotic. Also, a significantly greater percentage of runner tips cold stored for 2 months (16\%) failed to develop roots as compared to those stuck fresh $(1 \%)$ or stored for 1 month (7\%).

Field performance of plug plants. Runner production in the field from 13 Aug. to 26 Oct. differed among cultivars. The number of runners produced per plant ranged from 10.5 for ' $C$ handler' to 5.2 for 'Allstar' across treatments (Table 3 ). Differences in runner production were also noted among storage duration treatments. Plug plants produced from runner tips in the longest storage duration averaged 9.4 runners, while plants produced from freshly harvested runner tips produced an average of 7.0 runners (Table $3)$. Significant cultivar by storage duration effects were noted. 'Latestar' and 'Northeaster' were significantly affected by storage duration. Longer storage duration resulted in more runners being produced by the plants produced from the tips for these two cultivars. In contrast to the other cultivars, Chandler and B 27 produced more runners on plants generated from freshly harvested tips.

Cultivars differed significantly in crowns formed by November, ranging from a high of 5.3 crowns in 'Latestar' to a low of 1.7 for 'Chandler' (Table 4). Across cultivars, fall crown development was not significantly effected by runner tip storage durations. However, 'Allstar' and B 27 were significantly effected, with 'Allstar' producing fewer crowns with increasing storage duration and B 27 producing more crowns with 2 months storage. Significant cultivar by storage duration effects were noted (Table 4).

No storage treatment differences were noted in season of production, harvest duration, yield, average large fruit size, average fruit size, or in marketable yield of fruit. Cultivars varied significantly for all the aforementioned traits.
Significant cultivar by storage duration interactions were observed for average fruit size and marketable yield scores (Table 5).

\section{Discussion}

Greenhouse runner tip production. Genotypic variation for runner tip production in the greenhouse was observed. Breeders have noted differences in runner production among cultivars and the trait is a critical selection criterion in some breeding programs, to ensure success in nursery production. Poor runner producers have not become popular cultivars. Micro-

Table 1. Average fresh weight $(\mathrm{g})$ of runner tips from cultivars grown in a suspended-trough system in the greenhouse at Kearneysville, W.Va.

\begin{tabular}{|c|c|c|c|c|c|}
\hline \multirow[b]{2}{*}{ Cultivar } & \multicolumn{3}{|c|}{$\begin{array}{l}\text { Runner tip } \\
\text { harvest date }\end{array}$} & \multirow{2}{*}{$\begin{array}{c}\text { Significance } \\
\text { of harvest } \\
\text { period }\end{array}$} & \multirow[b]{2}{*}{ Mean } \\
\hline & 20-24 May & 14-24 June & 20 July & & \\
\hline Allstar & 3.3 & 5.2 & 5.0 & *** & 4.5 \\
\hline B 27 & 3.2 & 5.6 & 5.4 & $* * *$ & 4.8 \\
\hline Chandler & 2.9 & 3.9 & 4.5 & $* * *$ & 3.8 \\
\hline Latestar & 2.7 & 2.4 & 3.7 & $* * *$ & 2.9 \\
\hline Northeaster & 3.1 & 2.7 & 4.5 & $* * *$ & 3.4 \\
\hline Mean & 3.1 & 4.0 & 4.6 & & \\
\hline \multicolumn{6}{|c|}{ Analysis of variance } \\
\hline Cultivar (C) & $* * *$ & & & & \\
\hline Harvest $(\mathrm{H})$ & $* * *$ & & & & \\
\hline $\mathrm{C} \times \mathrm{H}$ & $* * *$ & & & & \\
\hline
\end{tabular}

**** Significant at $P \leq 0.001$.

Table 2. Cultivar (C) and storage duration (SD) effects on strawberry runner tip adventitious root and plug plant formation.

\begin{tabular}{|c|c|c|c|c|c|c|c|}
\hline \multirow[b]{3}{*}{ Cultivar } & \multicolumn{5}{|c|}{ Adventitious root formation } & \multirow{3}{*}{$\begin{array}{c}\text { Longest } \\
\text { root } \\
(\mathrm{cm})\end{array}$} & \multirow{3}{*}{$\begin{array}{l}\text { Commercially } \\
\text { acceptable } \\
\text { plug } \\
\text { formation } \\
(\%)^{\mathrm{z}}\end{array}$} \\
\hline & \multicolumn{3}{|c|}{$\begin{array}{l}\text { Runner tip storage duration } \\
\text { (month) }\end{array}$} & \multirow{2}{*}{$\begin{array}{c}\text { Significance } \\
\text { of storage } \\
\text { duration }\end{array}$} & \multirow[b]{2}{*}{ Mean } & & \\
\hline & 2 & 1 & 0 & & & & \\
\hline Allstar & 8.6 & 3.0 & 6.8 & $* * *$ & 6.1 & $4.3 a b^{y}$ & $72 \mathrm{~b}$ \\
\hline B 27 & 7.8 & 2.9 & 3.5 & $*$ & 4.7 & $3.8 \mathrm{~b}$ & $73 \mathrm{~b}$ \\
\hline Chandler & 9.9 & 7.1 & 15.8 & $*$ & 10.9 & $4.7 \mathrm{ab}$ & $73 \mathrm{~b}$ \\
\hline Latestar & 7.6 & 4.4 & 13.9 & $* *$ & 8.6 & $5.1 \mathrm{a}$ & $86 \mathrm{a}$ \\
\hline Northeaster & 8.3 & 2.9 & 10.8 & $* *$ & 7.3 & $4.4 \mathrm{ab}$ & $85 \mathrm{a}$ \\
\hline \multicolumn{8}{|c|}{ Storage duration } \\
\hline 2 months & 8.4 & & & & & 4.7 & $71 \mathrm{~b}$ \\
\hline 1 month & & 4.1 & & & & 4.0 & $77 \mathrm{~b}$ \\
\hline none & & & 10.1 & & & 4.7 & $87 \mathrm{a}$ \\
\hline \multicolumn{8}{|c|}{ Analysis of variance } \\
\hline Cultivar & & $* * *$ & & & & $*$ & $* *$ \\
\hline Storage & SD) & $* * *$ & & & & NS & $* * *$ \\
\hline $\mathrm{C} \times \mathrm{SD}$ & & $* *$ & & & & NS & NS \\
\hline
\end{tabular}

${ }^{2}$ Plugs that had cohesive rootballs which did not fall apart when lifted from the cell pack.

Plug plants were rated after 3 weeks on the mist propagation bench.

y Values in columns followed by the same lowercase letter were not significantly different at $P \leq 0.05$.

NS,*******Nonsignificant or significant at $P \leq 0.05,0.01$, and 0.001 , respectively.

Table 3. Cultivar and storage duration effects on production of runners in field plots at Beltsville, Md. (Fall 1999).

\begin{tabular}{|c|c|c|c|c|c|}
\hline \multirow[b]{2}{*}{ Cultivar } & \multicolumn{3}{|c|}{$\begin{array}{l}\text { Runner tip } \\
\text { storage duration } \\
\text { (months) }\end{array}$} & \multirow{2}{*}{$\begin{array}{c}\text { Significance } \\
\text { of } \\
\text { storage } \\
\text { treatment }\end{array}$} & \multirow[b]{2}{*}{ Mean } \\
\hline & 2 & 1 & 0 & & \\
\hline Allstar & 5.7 & 5.8 & 4.1 & NS & 5.2 \\
\hline B 27 & 8.5 & 6.8 & 7.1 & NS & 7.5 \\
\hline Chandler & 10.6 & 10.3 & 10.7 & NS & 10.5 \\
\hline Latestar & 9.8 & 9.2 & 7.9 & $*$ & 8.9 \\
\hline Northeaster & 12.3 & 9.2 & 5.0 & $* * *$ & 8.8 \\
\hline Mean & 9.4 & 8.2 & 7.0 & & \\
\hline \multicolumn{6}{|l|}{ Analysis of variance } \\
\hline Cultivar (C) & $* * *$ & & & & \\
\hline Storage duration (SD) & $* * *$ & & & & \\
\hline $\mathrm{C} \times \mathrm{SD}$ & $* * *$ & & & & \\
\hline
\end{tabular}

NS,**** Nonsignificant or significant at $P \leq 0.05$ and 0.001 respectively. 
propagated plants are known to produce more runners than traditionally propagated plants (Bish et al., 2001; Boxus et al., 1984; Swartz et al., 1981). Since this system uses mother plants derived directly from tissue culture, cultivars that previously would have been discarded due to poor propagation capacity, might prove to be useful in such a production scheme.

'Chandler', 'Allstar' and 'Northeaster' produced higher numbers of runner tips at the July harvest as compared to the earlier harvests. This experiment was designed to evaluate three storage durations, so runner tips were only harvested until 20 July, but all the cultivars were still producing runner tips in late July. This observation suggests cultivars such as 'Chandler', 'Allstar' and 'Northeaster' have the capacity to produce considerably more runner tips later in the season, a phenomenon noted in similar studies (Bish et al., 2001; Hicklenton and Reekie, 2002).

A different harvesting strategy could also improve the yield of runner tips. In a companion study to the present report (Takeda et al., 2004), 'Chandler' plants were allowed to produce long stolons with $>5$ daughter plants developing on each stolon. These plants produced $>30$ daughter plants on primary stolons and $>80$ daughter plants if the secondary stolons were not removed, in contrast to the 18 runner tips produced on primary stolons by 'Chandler' plants in this study.

The potential exists to improve production through earlier planting, manipulation of photoperiod (Downs and Piringer, 1955) and heat (Darrow, 1966) in the greenhouse. Earlier planting would allow a quicker commencement of runner production and a longer period for runner harvest, potentially leading to an increased production of runner tips.

Differences in weights of runner tips among cultivars and harvest dates were noted, although significant cultivar by harvest date interactions were observed (Table 1). Cultivars vary widely in the thickness and size of runners and daughter plants. In the breeding program at Beltsville, the numbered selection B 27 has consistently produced notably thick runners and large daughter plants. It is more common to find the first runners and daughter plants to be considerably smaller than those produced later in the season (Darrow, 1966). In general our results confirmed this phenomenon as runner tip size tended to increase at each successive harvest date. However, cultivars did vary, with 'Allstar' and B 27 producing the heaviest runner tips at the second harvest (Table 1). Future studies might investigate the impact of pinching off early, smaller runners on the number, size, and quality of runner tips produced later in the season.

Table 4. Cultivar and storage duration effects on strawberry crown numbers per plant in field plots at Beltsville, Md. (Fall 1999).

\begin{tabular}{|c|c|c|c|c|c|}
\hline \multirow[b]{2}{*}{ Cultivar } & \multicolumn{3}{|c|}{$\begin{array}{l}\text { Runner tip } \\
\text { storage duration } \\
\text { (months) }\end{array}$} & \multirow{2}{*}{$\begin{array}{c}\text { Significance } \\
\text { of } \\
\text { storage } \\
\text { treatment }\end{array}$} & \multirow[b]{2}{*}{ Mean } \\
\hline & 2 & 1 & 0 & & \\
\hline Allstar & 2.5 & 3.2 & 3.5 & $* *$ & 3.1 \\
\hline B 27 & 3.4 & 2.3 & 2.3 & $* * *$ & 2.7 \\
\hline Chandler & 1.7 & 1.8 & 1.7 & NS & 1.7 \\
\hline Latestar & 5.3 & 5.5 & 5.0 & NS & 5.3 \\
\hline Northeaster & 4.8 & 4.5 & 5.1 & NS & 4.8 \\
\hline Mean & 3.5 & 3.5 & 3.5 & & \\
\hline \multicolumn{6}{|l|}{ Analysis of variance } \\
\hline Cultivar $(\mathrm{C})$ & $* * *$ & & & & \\
\hline Storage duration (SD) & NS & & & & \\
\hline $\mathrm{C} \times \mathrm{SD}$ & $* * *$ & & & & \\
\hline
\end{tabular}

Table 5. Cultivar and storage duration effects on season (\% of fruit harvested through the second harvest of the season), average number of picks, average yield per plant, total yield, large fruit size, average fruit size, and marketable score for fruit harvested in the 2000 season from field plots at Beltsville, Md.

\begin{tabular}{|c|c|c|c|c|c|c|}
\hline Cultivar & $\begin{array}{c}\text { Early } \\
\text { season } \\
\text { yield } \\
(\%)\end{array}$ & $\begin{array}{c}\text { No. } \\
\text { of } \\
\text { picks }\end{array}$ & $\begin{array}{c}\text { Yield } \\
\text { (kg/plant) }\end{array}$ & $\begin{array}{l}\text { Large } \\
\text { fruit } \\
\text { size } \\
(\mathrm{g})^{\mathrm{z}}\end{array}$ & $\begin{array}{l}\text { Avg } \\
\text { fruit } \\
\text { size } \\
(\mathrm{g})\end{array}$ & $\begin{array}{c}\text { Marketable } \\
\text { score }^{y}\end{array}$ \\
\hline$\overline{\text { Allstar }}$ & $15.8 \mathrm{c}^{\mathrm{x}}$ & $8.6 \mathrm{bc}$ & $0.7 \mathrm{ab}$ & $21.6 \mathrm{c}$ & $12.6 \mathrm{c}$ & $5.3 \mathrm{~b}$ \\
\hline B 27 & $13.3 \mathrm{c}$ & $8.9 \mathrm{~b}$ & $0.6 \mathrm{~b}$ & $34.7 \mathrm{a}$ & $17.6 \mathrm{a}$ & $5.6 \mathrm{~b}$ \\
\hline Chandler & $27.1 \mathrm{~b}$ & $9.6 \mathrm{a}$ & $0.6 \mathrm{~b}$ & $19.5 \mathrm{c}$ & $12.9 \mathrm{c}$ & $6.3 \mathrm{a}$ \\
\hline Latestar & $0.0 \mathrm{~d}$ & $8.3 \mathrm{bc}$ & $0.8 \mathrm{a}$ & $23.0 \mathrm{c}$ & $11.4 \mathrm{~d}$ & $5.5 \mathrm{~b}$ \\
\hline Northeaster & $42.6 \mathrm{a}$ & $8.1 \mathrm{c}$ & $0.7 \mathrm{ab}$ & $27.8 \mathrm{~b}$ & $14.6 \mathrm{~b}$ & $5.5 \mathrm{~b}$ \\
\hline \multicolumn{7}{|l|}{ Storage duration } \\
\hline 2 months & 19.4 & 8.8 & 0.6 & 25.7 & 13.7 & 5.6 \\
\hline 1 month & 20.5 & 8.8 & 0.7 & 25.8 & 14.0 & 5.7 \\
\hline None & 19.5 & 8.7 & 0.7 & 24.5 & 13.8 & 5.6 \\
\hline \multicolumn{7}{|l|}{ Analysis of variance } \\
\hline Cultivar $(\mathrm{C})$ & $* * *$ & $* * *$ & $*$ & $* * *$ & $* * *$ & $* * *$ \\
\hline Storage duration (SD) & NS & NS & NS & NS & NS & NS \\
\hline $\mathrm{C} \times \mathrm{SD}$ & NS & NS & NS & NS & ** & $*$ \\
\hline
\end{tabular}

${ }^{2}$ Average weight in grams of the largest 10-fruit subsample evaluated at each pick during the 2000 season. ${ }^{y}$ Market score is a subjective rating for general appearance and marketability of harvested fruit, with 9 representing all fruit considered marketable and 1 representing no marketable fruit.

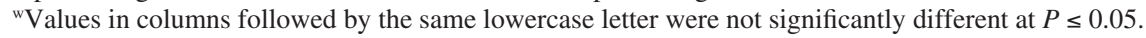

NS,*,**,****Nonsignificant or significant at $P \leq 0.05,0.01$, and 0.001 , respectively.
Genotypic influences on runner tip rooting andfieldperformance. During the rooting phase of plug plant production, cultivars differed in production and length of adventitious roots. Poor root formation could affect the efficiency of the plant production scheme. Interestingly, although B 27 was the cultivar that produced the least and shortest roots (not statistically significant) in these experiments, it produced as many rooted plug plants as 'Allstar' and 'Chandler' (Table 2). 'Chandler' produced more adventitious roots, but produced no more rooted plug plants than did B 27. 'Latestar' produced the longest roots of the cultivars tested and was statistically the same as 'Northeaster' for the highest percentage of rooted plug plants produced from runner tips in these experiments. Although significant cultivar differences for root number and length were noted, the impact of these factors on plug plant production do not appear to be critical as long as there is enough root structure to hold the media together for efficient field transplanting.

Cultivars varied widely for runner production in the field (Table 3). 'Latestar' and 'Northeaster' showed significant increases in the number of runners produced in response to the length of tip storage time. Runner production is critical for economical nursery propagation and in the cultural management of a fruit production field. Variation in runner production may result in some cultivars being better adapted than others to a specific management scheme, i.e., low runner-producing cultivars being developed for annual production systems, higher runner-producing types developed for traditional matted row systems.

Effects of size and cold storage duration on rooting and performance of plug plants. Rooting capacity of cold stored stem cuttings from herbaceous crops is maintained by reducing respiration, moisture loss, pathogen invasion, or ethylene buildup during storage (Paton and Schwabe, 1987). In this study, runner tips stored for two months produced $17 \%$ less adventitious roots than runner tips that were plugged without storage ( 8.4 vs. 10.1, Table 2 ). The capacity for root formation by runner tips may be related to their size at harvest. Generally, the runner tips from the third harvest were heavier than from the previous harvests with the exceptions being 'Allstar' and B 27 (Table 1).

Another factor contributing to the loss of rooting capacity in cold stored tips may be the result of microbial activity degrading tissue integrity. The percentage of tips that had become necrotic at the nodal section and showed no sign of root development following 1 week on the propagation bench was higher among tips stored for 2 months (data not shown). In this study, fungicides were not used in runner tip production, cold storage, or in the rooting phase.

When the plug plants were established in field plantings, significant differences in runner production were noted among storage treatments with a significant cultivar $\times$ treatment interaction (Table 3). With the exception of 'Chandler', runner tips stored for 2 months produced more runners in the field than fresh harvested tips. Plants produced from runner tips that were stored two months produced nine runners per plant, 
compared to seven runners for those derived from freshly harvested tips.

The fact that longer runner tip storage resulted in increased runner production in the field has important ramifications for strawberry field production. Newer annual production systems being adapted worldwide are designed with yields based on high-density plantings $(43,000$ plants/ha) of multi-crowned mother plants that produce large numbers of flowers. In such systems, runner production has been characterized as having an antagonistic relationship with flowering (Battey etal., 1998), and by extension, fruit yields, and is viewed as a negative trait. In part this is due to the fact that one of the management tasks in the annual production system is runner removal, which has been estimated to cost \$150/ha/removal operation (O'Dell and Williams, 2000). An increase in runner production by mother plants from a micropropagation scheme could lead to increased labor operations and increased production costs in an annual production system.

For a runner tip plant production scheme to be economical, cultivars that do not produce excessive runners following cold storage would need to be selected in the breeding process. This is important considering the positive effect of cold conditioning of plugs on fruit yield (Bish et al., 1997; Durner et al., 1986). Cultivars in this study varied in response to cold storage. For example, plug plants of 'Northeaster' derived from tips stored for two months produced two times as many runners as plug plants resulting from tips that were planted immediately after harvest. In contrast, storage treatment had no effect on runner production in 'Chandler' strawberry. Strawberry cultivars like 'Chandler', that do not respond to runner tip storage will be critical to the success of a greenhouse-based runner tip propagation scheme.

Although cultivars differed significantly in crowns formed in the field, there were no significant effects of storage treatment. The plant crown numbers in each of the three treatments across cultivars were almost identical, suggesting that cold storage of tips for as long as two months will have no measurable impact on crown formation in an annual production system.

In this study, no significant differences were found in yield, fruit size, quality or season due to storage duration, although a trend was noted for decreasing yield per plant as runner tip storage time increased. In contrast to these results, Crawford et al. (1998) reported that among 'Chandler' runner tips placed in cold storage for $4,3,2$, or 1 month, those stored for two months produced the highest early and marketable yields and the largest fruit.

Runner tips stored for two months in our study produced significantly fewer good plug plants than did the freshly harvested runner tips, but had yields equal to plants that were propagated from runner tips that had not been stored.

Results from these experiments demonstrate that large numbers of runner tips can be produced from greenhouse-grown mother plants grown in suspended gutters with a nutrient-film technique system. Runner tips can be stored 1 to 2 months and still produce plug plants that yield on a par with plants produced from freshly harvested runner tips. However, long cold storage of runner tips increased the rate of tips that failed to root under mist propagation, resulting in tip to transplant conversion ratio unacceptable to commercial strawberry propagators (David Lankford, Davoncrest Farms, Hurlock, Md., personal communication). We did not determine whether the failure of these stored runner tips to produce adventitious roots under mist was due to microbial activity. Additional research is needed to develop a more efficient greenhouse tip production system and to improve the viability of cold stored runner tips. Future studies should consider cold storage temperatures, humidity, and atmospheric gas compositions, fungicide treatments, and sanitation practices that might lead to increased storage duration and tip to transplant conversion ratios. In addition, the economics of various components of the system should be evaluated to determine the practicality of the system for commercial propagators.

\section{Literature Cited}

Battey, N.H., P. LeMiere, A. Tehranifar, C. Cekic, S. Taylor, K.J. Shrives, P. Hadley, A.J. Greenland, J. Darby, and M.J. Wilkinson. 1998. Genetic and environmental control of flowering in strawberry, p. 111-131. In: K.E. Cockshull, D. Gray, G.B. Seymour, and B. Thomas (eds.). Genetic and environmental manipulation of horticultural crops. CAB Int. Publ. Cambridge, U.K

Bish, E.B., D.J. Cantliffe, G.J. Hochmuth, and C.K. Chandler. 1997. Development of containerized strawberry transplants for Florida's winter production system. Acta Hort. 439:461-468.

Bish, E.B., D.J. Cantliffe, and C.K. Chandler. 2001. A system for producing large quantities of greenhouse-grown strawberry plantlets for plug production. HortTechnology 11:636-638.

Black, B.L., J.M. Enns, and S.C. Hokanson. 2002. A comparison of temperate-climate strawberry production systems using eastern genotypes. HortTechnology 12:670-675.

Boxus, P., C. Damiano, and E. Brasseur. 1984 Strawberry, p. 453-486. In: D.A. Ammirato, P.V. Evans, W.R. Sharp, and Y. Yamada (eds.). Handbook of plant cell culture. vol. 3. Crop species. Macmillan, New York.

Crawford, T.D., D.G. Himelrick, J.L. Sibley, and J.A Pitts. 1998. Effects of cold storage and cell pack size on the production of 'Chandler' strawberry plug plants. Adv. Strawberry Res. 17:52-57.

Darrow, G.M. 1966. The strawberry, history, breeding and physiology. Holt, Rinehart and Winston, New York.

Downs, R.J. and A.A. Piringer. 1955. Differences in photoperiodic responses of everbearing and June-bearing strawberries. Proc. Amer. Soc. Hort. Sci. 66:234-236.

Durner, E.F., E.B. Poling, and E.E. Albregts. 1986. Early season yield responses of selected strawberry cultivars to photoperiod and chilling in a Florida winter production system. J. Amer. Soc. Hort. Sci. 112:53-56.

El-Farhan, A.H. and M.P. Pritts. 1997. Water requirements and water stress in strawberry. Adv. Strawberry Res. 16:5-12.

Galletta, G.J., A.D. Draper, and H.J. Swartz. 1981. 'Allstar' strawberry. HortScience 16:792-794.
Galletta, G.J., J.L. Maas, J.M. Enns, A.D. Draper, J.A. Fiola, J.C. Scheerens, and D.D. Archbold. 1995a. 'Northeaster' strawberry. Adv. Strawberry Res. 14:73-78.

Galletta, G.J., J.L. Maas, J.M.Enns, A.D. Draper, J.A Fiola, J.C. Scheerens, D.D. Archbold, and J.R. Ballington, Jr. 1995b. 'Delmarvel' strawberry. HortScience 30:1099-1103.

Galletta, G.J., J.L. Maas, J.M. Enns, J.C. Scheerens, R.J. Rouse, and R.F. Heflebower, Jr. 1996. 'Latestar' strawberry. HortScience 31:1238-1242.

Hicklenton,P.R. and J.Y-C. Reekie. 2002. The nursery connection: Exploring the links between transplant growth and development, establishment, and productivity, p. 136-146. In: S.C. Hokanson and A.R. Jamieson(eds.). Strawberry research to 2001 ASHS Press, Alexandria, Va.

Leandro, L.F.S., M.L. Gleason, F.W. Nutter, Jr., S.N. Wegulo, and P.M. Dixon. 2001. Germination and sporulation of Colletotrichum acutatum on symptomless strawberry leaves. Phytopathology 91:659-664.

Maas, J.L. 2000. Opportunities to reduce the potential for disease infection and spread with strawberry plug plants. Acta Hort. 513:409-414.

O'Dell, C.R. and J. Williams. 2000. Hill system plastic mulched guide for colder areas. Va. Tech. (Blacksburg) Va. Coop. Ext. Publ. 438-018.

Paton, F. and W.W. Schwabe. 1987. Storage of cuttings of Pelargonium $\times$ hortorum Bailey. J. Hort. Sci. 62:79-87.

Poling, E.B. 1993. Strawberry plasticulture in North Carolina: II. Preplant, planting, and postplanting considerations for growing 'Chandler' strawberry on black mulch. HortTechnology 3:383-393.

Poling, E.B. and E.F. Durner. 1986. Annual strawberry hill cultural system in Southeastern North Carolina. HortScience 21:240-242.

Poling, E.B. and K. Parker. 1990. Plug production of strawberry transplants. Adv. Strawberry Prod. 9:37-39.

Reynolds, K.M.,M.A. Bulger,L.V.Madden, and M.A Ellis. 1987. New methods using simulated rain to study the splash dispersal of plant pathogens. Phytopathology 77:921-926.

SAS Institute, Inc. 2001. The SAS system for Windows. Release 8.02. SAS Inst., Inc., Cary, N.C.

Swartz, H.J., G.J. Galletta, and R.H. Zimmerman. 1981. Field performance and phenotypic stability of tissue culture-propagated strawberries. J. Amer. Soc. Hort. Sci. 106:667-673.

Takeda, F. 1999. Out-of-season greenhouse strawberry production in soiless substrate. Adv. Strawberry Res. 18:4-15.

Takeda, F., P.R. Adler, and D.M. Glenn. 1997. Strawberry production linked to aquaculture wastewater treatment. Acta Hort. 439:673-677.

Takeda, F. and S.C. Hokanson. 2002. Effects of transplant conditioning on 'Chandler' strawberry performance in a winter greenhouse production system, p. 132-135. In: S.C. Hokanson and A.R. Jamieson (eds.). Strawberry research to 2001. ASHS Press, Alexandria, Va.

Takeda, F., S.C. Hokanson, and J.M. Enns. 2004 Influence of daughter plant weight and position on strawberry transplant production and field performance in annual plasticulture. HortScience 39(7):1592-1595.

Voth, V. and R.S. Bringhurst. 1984. 'Chandler'. Plant Patent 5262, 24 July.

Voth, V. and R.S. Bringhurst. 1990. Culture and physiological manipulation of California strawberries. HortScience 25:889-892.

Yang, X., L.L. Wilson, L.V. Madden, and M.A. Ellis. 1990. Rain splash dispersal of Colletotrichum acutatum from infected strawberry fruit. Phytopathology 80:590-595. 